\title{
Organizational Values as the Basis for Business Excellence
}

\author{
IVAN MALBAŠIĆ \\ University of Zagreb, Croatia \\ ivan.malbasic@foi.hr \\ BRUNO BELUŽIĆ \\ Vindija Ltd, Croatia \\ bruno.beluzic@gmail.com \\ NIKOLINA POSARIĆ \\ University of Zagreb, Croatia \\ nikolina.posaric@foi.hr
}

Organizational values play an increasingly important role in contemporary organizations - they intertwine all segments of business and greatly affect the direction of the organization's business strategy. The purpose of this paper is to note that the organizational values that permeate all business segments under modern business conditions form the foundation for the excellence of business organizations. In this regard, we first introduce Kanji's Business Excellence Measurement System (КВЕ M $)$ as a starting point for understanding business excellence. According to $\mathrm{KBEMS}$, business excellence is determined by measuring the satisfaction level of customers, employees and other stakeholders to obtain a comprehensive assessment of organizational performance. Specifically, кв E M consists of two main aspects-leadership and organizational values. In the central part of the paper, we present a case study of Yum! Brands, one of the world's largest fast food companies. Particular emphasis is placed on the detailed presentation and explanation of the basic organizational values of Yum! Brands Company based on two sources of information-espoused values listed on the official web site of the company and various external sources of information from which external stakeholders assess the company's value orientation. Finally, we analyzed the organizational values of Yum! Brands from the perspective of кв Е $\mathrm{MS}$. This case study shows that organizational values are the real foundation for business excellence in Yum! Brands. In this context, we considered the relationship between organizational values and key components of кв Е MS. This study can therefore serve as an example of putting organizational values into the function of increasing organizational performance, with the ultimate goal of creating organizational excellence.

Key words: organizational values, business excellence, Kanji's Business Excellence Measurement System, organizational performance, Yum! Brands Company https://doi.org/10.26493/1854-4231.13.265-279 


\section{Introduction}

Values have always played an important role in the lives of people. Values have built not only relationships between people but among society as a whole. Along with the development of society, business have also evolved, and thus, business relations have been increasingly permeated with values that prevail in societies. Ultimately, the importance of managing organizational values, to a large extent, was identified in the 21st century, during which organizations acted under the conditions of globalization and business expansion around the world. Globalization is one of the main reasons why contemporary organizations need to adapt to different cultures and value systems.

As social values relate to an individual and society as a whole, organizational values apply to employees individually and to the company as a whole. The existence of organizational values largely governs the relationships within organizations. Organizational values determine the ways in which employees work in certain situations, so they can also accelerate business processes and decision-making. It is known that organizational goals are a very important element of modern organizations. When management sets goals, it is very important that these goals are aligned with the organizational values that have been established and with which each organization's member must comply.

All of the above-mentioned points show that organizational values play an increasingly important role in the business activities of modern organizations. Organizational values are an important element of an organization's excellence in business. Business excellence, which is currently manifested by achieving top results in all areas of the business, would not be possible without clearly defined principles that all of an organization's members must follow and apply in everyday activities. Therefore, the importance of organizational values in contemporary business is clear.

Organizational values and business excellence are related concepts because without organizational values that run every-day work activities and are manifested through day-to-day business practice, it is impossible to achieve business excellence in any business segment. Organizational values are the guiding principle for management and employees and have the aim of achieving top results and greater effectiveness. The role of balanced organizational values is particularly emphasized, with the aim of satisfying the interest of different stakeholders at the same time, which is, in some way, based on business excellence itself. Achieving top performance in all seg- 
ments of business is an important challenge for modern organizations, which also helps them achieve the goal of being recognized for overall business excellence.

In this paper, we first consider the concept of organizational values and contemporary trends in organizational values research. Then, we present the concept of business excellence based on organizational values. Finally, we analyze the organizational values of the Yum! Brands Company from the perspective of the concept of business excellence and present conclusions and implications for further research.

\section{Literature Review}

DETERMINING THE CONCEPT OF ORGANIZATIONAL VALUES

Values have been studied by many people throughout history. However, the first scientific research that recognized certain rules and the impact of organizational values on businesses was performed recently. In establishing the value dimension as an important link in business success, Rokeach (1973) made a special contribution to the literature. According to Rokeach, values are persistent beliefs that certain modes of behavior, or the ultimate social condition, are more acceptable than the opposite behaviors and/or states. Schwartz (1992) defines values as desirable goals of different importance and as priorities that transcend specific situations, where the same priorities act as guiding principles in human life. From these two definitions, it is clear that values are the foundation of a company or individual when they are making decisions or taking certain actions.

When we look at an organization as an entity, we can say that each organization has and develops its own specific values. Organizational values can be defined as a set of ideas and beliefs that an organization's members should take to achieve organizational goals and ideas on behaviors that they should follow (Sikavica, BahtijarevićŠiber, and Pološki Vokić 2008). Enz (1988) agreed with this view and states that organizational values are the beliefs of an organizations' members about the goals and means that organizations must identify in business. Lencioni (2002) claims that organizational values are the basic principles that govern all organizational activities. We can therefore conclude that organizational values play an important role in the business of modern organizations; the acceptance of organizational values as the fundamental principles of business is the basis for the success of achieving organizational goals. 
Viewing organizational values with greater importance gradually led to a change in research on this topic, resulting in a typology of organizational values with several different types of values. Organizational values can be divided into (at least) seven characteristic types (according to Malbašić 2011): (1) goals and the methods of their achievements (terminal and instrumental values); (2) importance for the organization (core and operational values); (3) organizational tendency for organizational changes (defensive, stabilizing and growth values); (4) acceptance within an organization (espoused, actual and desired values); (5) representation, i.e., uniformity in an organization (prevailing or shared and additional values); (6) their historical context (old and new values); and (7) the level of formalization (implicit and explicit values).

One of the most important classifications of organizational values is the classification according to whether the organizational values are espoused, actual or desired values. Espoused organizational values are those for which organizations state that they govern their business activities (Hultman and Gellerman 2002). These values can often be found in organizational acts or are highlighted on the company's website. On the other hand, actual organizational values are the values that actually govern the current organizational behavior. Regardless of whether they are clearly stated in organizational acts or whether organizations are not aware of them, they really affect day-to-day business activities (Malbašić 2011). Desired organizational values are the values to which an organization wants to move towards and that the organization seeks to be the future foundation on which it will build its business. Desired organizational values can also be read from an organizational vision that depicts the direction in which the organization is going, and for that reason, these values are a great help to organizations that have defined good visions (Hultman and Gellerman 2002).

From contemporary research on organizational values, we must mention a growing research interest in balanced organizational values. The concept of balanced organizational values is based on the stakeholder approach suggested by Freeman (1984), the main idea of which lies in the need to meet the interests of various stakeholders, and to meet these interests, organizational values must be balanced. There are several models of organizational values through which different authors have tried to explain the basic idea of balanced orga- 
nizational values. A recent approach is a Mission-based model of organizational values (Malbašić, Rey, and Potočan 2015.). This model is based on the idea of Cardona and Rey (2008). The basic categories of organizational values under this model are: business values, relational values, development values, and contribution values. The Mission-based model of organizational values assumes that, to some extent, values from all four fundamental categories should be represented in a particular organization, given that each category of values is directed towards specific stakeholders. The same principle is based on the development of an organizational mission that communicates messages to different stakeholders.

Since it has been recognized that organizational values are increasingly becoming the foundation of modern business, future research on organizational values should connect the concept of organizational values and business excellence, which is one of the new trends in the study of organizational values. One of the first authors who connected organizational values and business excellence is Kanji - his business excellence measurement system is based on two important aspects: leadership and organizational values (Kanji 2002). In that sense, Kanji's system plays an important role in connecting organizational values and business excellence.

\section{BUSINESS EXCELLENCE BASED ON ORGANIZATIONAL VALUES}

It is evident that organizational values play an increasingly important role in modern business organizations. Organizational values are intertwined with all segments of business activities and greatly affect the direction of the business. By incorporating organizational values across all segments of business, values under modern business conditions for the foundation for business excellence (Kanji 2002; Kanji and Moura e Sá 2002; Zdrilić and Dulčić 2016).

Business excellence can be defined as a high level of maturity of the management of an organization and its achievement of results (Zdrilić and Dulčić 2016, 147). Excellent organizations are those that are trying to satisfy all interested parties via their achievements, how they achieve their goals and what they can achieve in the future. To achieve business excellence, it is important to focus on both financial and non-financial performance measurements. Likewise, to achieve business excellence, it is important that organizations apply the principles of total quality management (TQM) (Zdrilić and Dulčić 2016).

Kanji (1998) defined business excellence as a way of measuring the satisfaction of customers, employees and other stakeholders to 


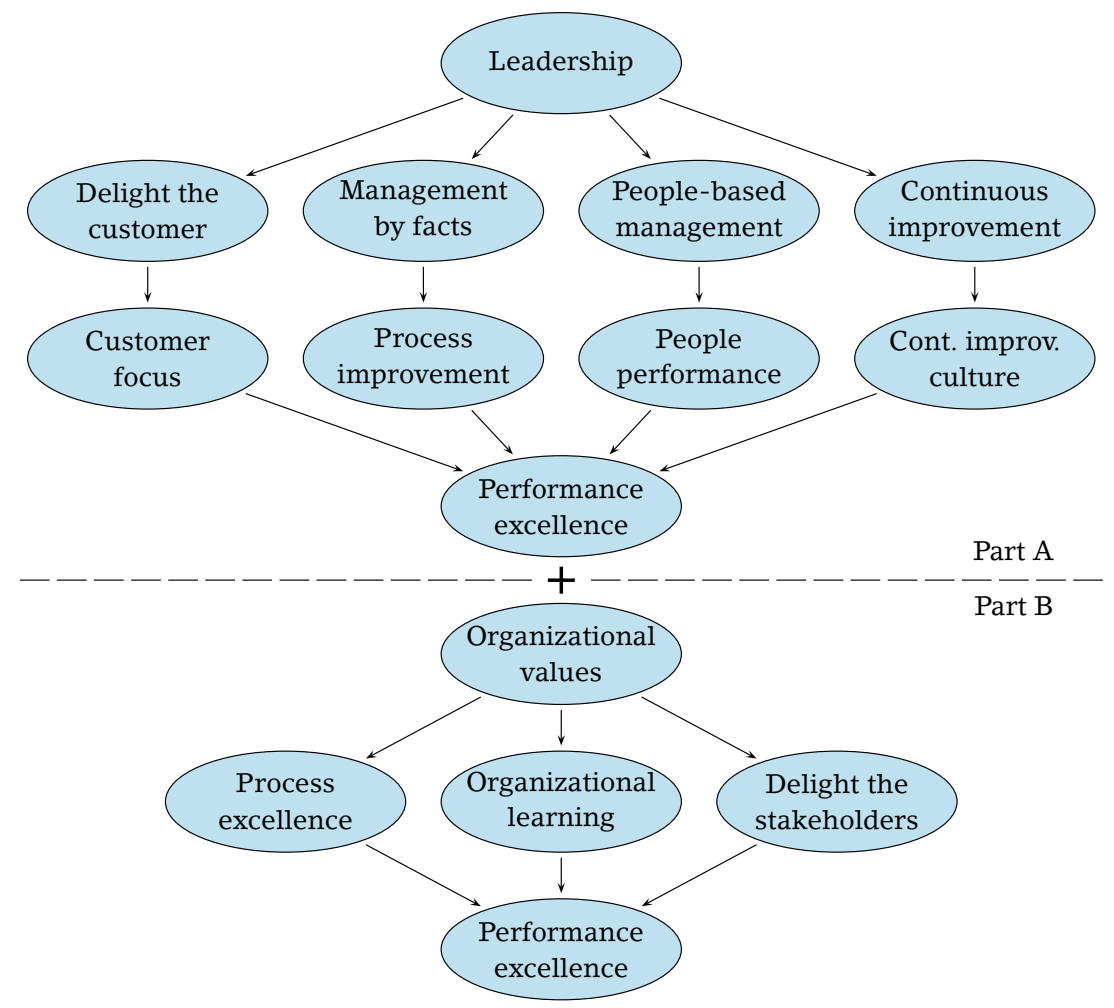

FIGURE 1 Kanji's Business Excellence Measurement System (adapted from Kanji 2002, 1117)

obtain a comprehensive assessment of organizational success. In this regard, he also developed Kanji's Business Excellence Measurement System (KBEMS). Kanji's system is another important contribution to measuring business excellence, along with well-known models, such as the EFQM Excellence Model, Balanced Scorecard (BSC), Deming Circuit, Ericsson's Business Excellence Model, and many others. This system, besides being recognized as another important system in a multitude of business excellence models, has also contributed to connecting the concepts of organizational values and business excellence.

квемS is based on Kanji's Business Excellence Model (квем) and Kanji's Business Scorecard (квS). This system specifically takes external and internal stakeholders of organizations into account in a special way through two fundamental aspects: leadership and organizational values. Figure 1 shows Kanji's Business Excellence Mea- 
surement System. KBEMS consists of two main parts-one part is focused on leadership (Part A) and the other part on organizational values (Part B). Through a customer focus, process improvement, people performance and a culture of continuous improvement, leadership leads to excellent performance, which means that leaders are the most important driving force for achieving business excellence.

On the other hand, through process excellence, organizational learning and pleasing stakeholders, organizational values also lead to excellent performance. Both parts-leadership and organizational values-should be applied simultaneously because they form a complementary model of business excellence. The difference between these two parts in квЕмs lies in the fact that leadership is more concentrated on internal stakeholders, while organizational values are more concentrated on issues relevant to external stakeholders of organizations. In order for a given organization to have a finite index of business excellence, it is necessary to sum both parts (leadership and organizational values), divide by two, and multiply by ten. From this model, it is clearly seen that organizational values, together with the variables of leadership, are the foundation for achieving business excellence. Moreover, the organization will hardly be excellent if its business excellence measurement system is not related to or based on organizational values (Kanji 2002).

\section{A Case Study of a Company Whose Business is Based on Values and Business Excellence: Yum! Brands, Inc.}

ABOUT YUM! BRANDS, INC.

Yum! Brands is one of the world's largest fast food companies. In addition to doing business in the United States, the company also operates in 130 countries around the world, with over 60,000 employees and 1.5 million associates. This multinational company was founded in 1997 by a spin-off of three fast-food chains from Pepsi Co, Inc. The fast food chains that emerged from the company were run under three distinct brands: KFC, Taco Bell and Pizza Hut. To ensure the successful business activities of these chains in the market after the spin-off process, it was necessary to set up a new company that would unify the business operations of all three chains; thus, Yum! Brands was created. The headquarters of the newly founded company is in Lousville, Kentucky. David Novak was appointed executive director of the company until the end of 2013, when he was replaced by Greg Creed (see http://www.yum.com). In 2017, accord- 
ing to data from its annual report, the company took 472nd place on the Fortune 500 list of the largest companies in the world.

ESPOUSED ORGANIZATIONAL VALUES OF YUM! BRANDS INC.

For a long time, Yum! Brands has devoted considerable attention to communicating its core values. For this purpose, Yum! Brands have developed a special brochure representing their organizational values and explanations of what each value means for the company. The organizational values that drive Yum! Brands have become the main driving force of all their business activities as well as of other socially responsible businesses. Table 1 shows the espoused organizational values of Yum! Brands, along with explanations of what each organizational value means for the company.

Based on the espoused values of Yum! Brands, we can recognize six core organizational values-trust in employees, an orientation toward customers, aspiration to success, knowledge-based business, teamwork, and recognition of the best employees. Yum! Brands is a multinational company, and for that reason, it is very important that it has defined universal organizational values pertaining to all of its branches and restaurants around the world so that the defined organizational values help achieve success and business excellence. Yum! Brands is trying to make both its employees and customers aware of these organizational values.

Aside from presenting organizational values, the Yum! Brands company's website shows many examples of how these values are lived in everyday practice. Since 2012, the company has participated in an international study named Great Place to Work (GPTw), which examines certain segments of work and employees' relationships in organizations, all with the aim of examining employees' satisfaction. In 2014, 91\% of Yum! Brands employees participated in the survey, and $81 \%$ of the participants said that Yum! Brands is a great place to work. To provide the professionalism of its employees in providing quality services, Yum! Brands has introduced training and mentoring programs. Furthermore, Yum! Brands argues that focus, thinking, and action are the three elements that are important for achieving successful results with employees (see http://www.yum.com).

FURTHER INFORMATION OF THE VALUES OF YUM! BRANDS, INC.

For a more complete picture of Yum! Brands' organizational values and to assess the extent to which the company's activities are consistent with the values that they promote, it is also necessary to consider some external sources of information. This approach allows for 
TABLE 1 Espoused Organizational Values of Yum! Brands, Inc.

\begin{tabular}{|c|c|}
\hline \multicolumn{2}{|c|}{$\begin{array}{l}\text { Organizational Explanation of organizational value } \\
\text { value }\end{array}$} \\
\hline $\begin{array}{l}\text { Believe in all } \\
\text { people }\end{array}$ & $\begin{array}{l}\text { We trust in positive intentions and believe everyone has the poten- } \\
\text { tial to make a difference. We actively seek diversity in others to ex- } \\
\text { pand our thinking and make the best decision. We coach and sup- } \\
\text { port every individual to grow to their full capability. }\end{array}$ \\
\hline $\begin{array}{l}\text { Be restaurant } \\
\text { and customer } \\
\text { maniacs } \ldots \\
\text { Now! }\end{array}$ & $\begin{array}{l}\text { We love running great restaurants, and our customers rule. We act } \\
\text { with urgency to ensure every customer sees it and feels it in every } \\
\text { restaurant. We make sure we have great RG Ms who build great } \\
\text { teams. We are maniacal about the rigorous execution of our core } \\
\text { processes to deliver our Brand Standards as our \#1 brand building } \\
\text { initiative. It's the foundation for making customer mania come alive. }\end{array}$ \\
\hline $\begin{array}{l}\text { Go for break- } \\
\text { through }\end{array}$ & $\begin{array}{l}\text { We begin by asking ourselves, 'What can I do Now to get break- } \\
\text { through results in my piece of Yum?!' Our intentionality drives step } \\
\text { change thinking. We imagine how big something can be and work } \\
\text { future-back, going full out with positive energy and personal ac- } \\
\text { countability to make it happen. }\end{array}$ \\
\hline $\begin{array}{l}\text { Build know } \\
\text { how }\end{array}$ & $\begin{array}{l}\text { We grow by being avid learners, pursuing knowledge and best } \\
\text { practices inside and outside our company. We seek truth over har- } \\
\text { mony every step of the way. We consistently drive outstanding ex- } \\
\text { ecution by scaling our learnings into process and tools around } \\
\text { what matters most. Breakthroughs come when we get people with } \\
\text { knowledge thinking creatively. }\end{array}$ \\
\hline $\begin{array}{l}\text { Take the hill } \\
\text { teamwork }\end{array}$ & $\begin{array}{l}\text { We team together to drive action versus activity. We discuss the } \\
\text { undiscussable, always promoting healthy debate and healthy deci- } \\
\text { sions. Our relationships allow us to ask the earth of each other. We } \\
\text { make specific verbal contracts to get big things done with urgency } \\
\text { and excellence. }\end{array}$ \\
\hline $\begin{array}{l}\text { Recognize! } \\
\text { Recognize! } \\
\text { Recognize! }\end{array}$ & $\begin{array}{l}\text { We attract and retain the best people and inspire greatness by be- } \\
\text { ing world famous for recognition. We love celebrating the achieve- } \\
\text { ment of others and have lots of fun doing it! }\end{array}$ \\
\hline
\end{tabular}

Notes Adapted from Yum! Brands (http://www.yum.com).

a more objective consideration of organizational values, and in this way, we can test the extent to which the espoused values match the actual values, i.e., the values that really affect the organizational behavior and the decisions that are made in the company.

One of main organizational values of Yum! Brands is its orientation towards customers. This organizational value represents that customers are most important factor, and the company's goal is meet customers' needs and ensure a pleasant stay for them in their restaurants. This organizational value also refers to removing and remedying the disadvantages associated with the inconvenience that customers might encounter in the company's restaurants. Over the 
years, Yum! Brands experienced some inconveniences on several occasions, such as what happened in Mississippi in 2014, when the family of a girl who had been attacked by a dog accused a restaurant employee of forcing them to leave the restaurant. Since news of the incident rapidly spread to the public through social networks, management reacted quickly with a public apology to the family, initiated an internal investigation, and committed to pay a certain amount of money to treat the girl (Fray 2016). In this way, the company wanted to show concern for their customers because for Yum! Brands, feelings toward their customers are important and they want to ensure that customers feel comfortable when visiting their restaurants, regardless of their physical appearance or any disease. Although the investigation showed that the reported incident did not occur and the family refused to receive money for the treatment of the girl, Yum! Brands donated money to the foundation of one plastic surgeon who offered medical assistance to the girl (Fray 2016). This case shows great care for its customers by Yum! Brands and how this company seeks to compensate for and remedy the consequences of possible damage to its customers.

An important business segment of Yum! Brands is also talent management. This concept appeared in the professional literature at the beginning of the 1990s. This concept is largely oriented towards the development of human resources in enterprises. To keep up with global trends, Yum! Brands has embedded this concept into its business and is trying to develop the human potential of employees (Sinha and Kumar 2012). By developing human resources, Yum! Brands seeks to contribute to better development and to increase its competitiveness on the market. By placing an emphasis on human resource development, Yum! Brands ensures a better development of the entire business and obtains a greater ability to adapt to new trends that occur in the market.

Yum! Brands also saw a great opportunity for sharing information through social networks (Sinha and Kumar 2012). Using social networks is particularly useful for sharing information between the company's employees and communicating ideas and values that show that Yum! Brands cares for existing and potential customers. Using social networks has the great advantage of allowing communication between employees in different countries. In this way, communication between employees becomes simpler and cheaper for the company.

An important segment in the company's business is also the leadership that is responsible for making the most important decisions.

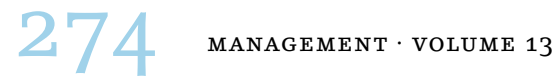


There is a large problem for the company in regard to a change in leadership because there are problems with introducing a leadership change and there is the possibility of conflict between employees and the new leadership. To eliminate the problems associated with a leadership change, Yum! Brands conducts so-called executive leadership development. This method of leadership development is based on the fact that existing managers are involved in the development of future managers, i.e., current managers are the mentors of future managers (Groves 2007). Through the use of this model of future leadership development, the company prevents the potential difficulties of new leadership in running the company and reduces possible conflicts between employees and new leadership. The advantage of this method is that it is based on mentoring, or more precisely, existing managers help future managers to develop the skills that they need to perform certain managerial jobs.

In addition to trying to create additional value for its shareholders, Yum! Brands is striving to help endangered people around the world. To achieve this goal, Yum! Brands has been a partner of the World Food Program (WFP) since 2007 (Kraak et al. 2012). The fundamental objective of this organization is to fight hunger in all parts of the world. Yum! Brands helps this organization through donations to one of its programs - World Hunger Relief Campaign, which has provided more than 148 million meals, and in the period from 2007 to 2014, secured a donation in the amount of more than 185 million dollars (Emberland 2014). This support shows that Yum! Brands is actively participating in helping the most vulnerable people around the world and to create a better society. By engaging in socially responsible activities, Yum! Brands wants to show its human side and wants to contribute to the company's betterment.

\section{BUSINESS EXCELLENCE OF YUM! BRANDS BASED ON VALUES}

The previous section provides an analysis of the espoused organizational values of Yum! Brands, which are recognized through the activities that the company undertakes. Yum! Brands achieves business excellence in all areas of their business operations, as indicated by achieving top business results, social responsibility and care for employees and customers. The business excellence of Yum! Brands is also oriented towards external and internal stakeholders. Therefore, the business excellence of Yum! Brands can best be described through KBEMS, which is based on leadership and organizational values and thus focuses on internal and external stakeholders.

Leadership has a major role in achieving business excellence, and 
Yum! Brands is a company that devotes great attention to leadership through the introduction of executive leadership development in which the existing leadership is involved in the development of future leadership through mentoring. On the other hand, leadership plays an important role in customer orientation, managing talent, human resource development and fostering a culture of continuous improvement. This role is manifested through customer care and efforts to overcome any inconvenience that may arise with customers, as shown in the example of the girl who was attacked by a dog. Furthermore, management also cares about their employees and their career development, which led $81 \%$ of employees in the survey conducted in 2014 to express satisfaction with their work at Yum! Brands. The company's overall business is focused on a culture of continuous improvement that is reflected in the leadership's dedication to facilitating work and communication within the company, monitoring trends in information and communication technology and introducing social networking for employees across the globe.

Another important aspect of Yum! Brands business excellence is reflected in its organizational values, which are the foundation of the company's business. Yum! Brands highlights six fundamental organizational values: trust in employees, customer orientation, aspiration to success, knowledge-based business, teamwork, and recognition of the best employees. Organizational values are intertwined with the core philosophy of leadership that emphasizes employees, customers, learning and teamwork. In the previous section, there are several examples that confirm that these values are actually present in the organization and affect the company's decision-making. The organizational values are also strongly influenced by the achievement of the satisfaction of all stakeholders, which is particularly evident through the company's socially responsible business. Namely, Yum! Brands devotes a large amount of attention to humanitarian work and environmental protection. The company is actively involved in making donations to the most vulnerable people in the world who are struggling with poverty and hunger. Likewise, Yum! Brands is actively involved in reduced environmental pollution by utilizing spent fuel oil from fryers.

All of the above evidence suggests that Yum! Brands' business excellence is based on strong leadership and organizational values. Based on the evidence presented, the Yum! Brands business excellence model is shown in figure 2 . The model clearly shows two fundamental aspects of business excellence-leadership and organi-

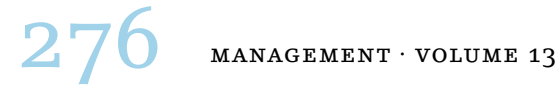




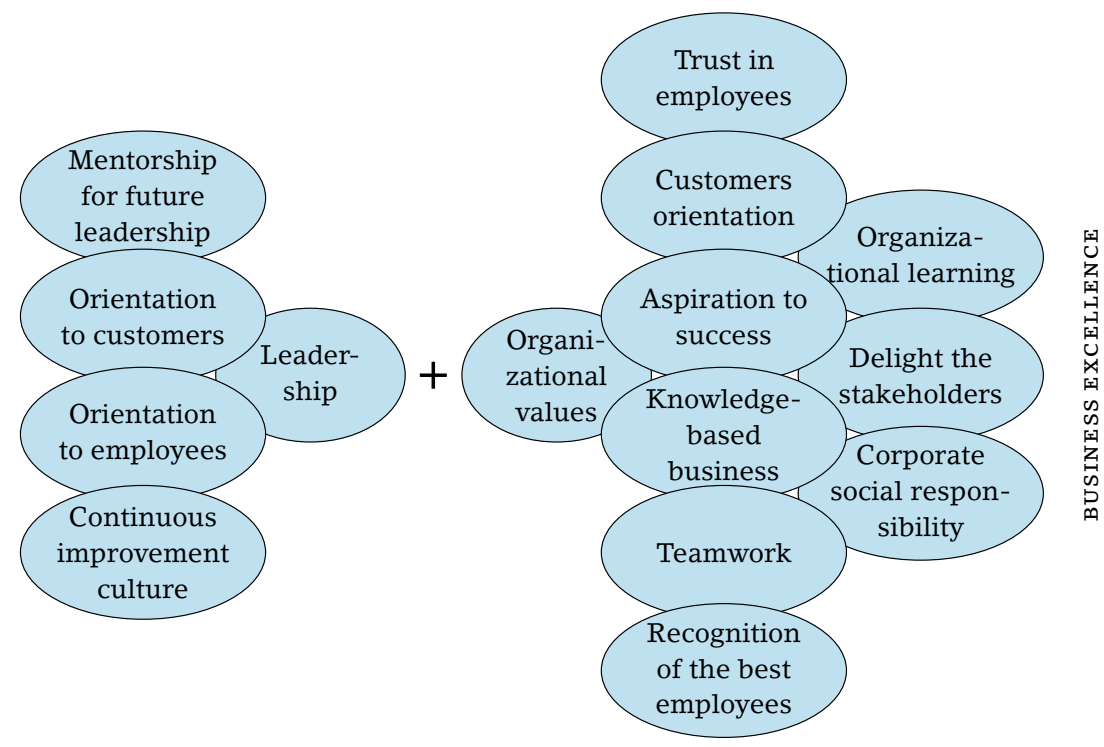

FIGURE 2 Yum! Brands Business Excellence Model

zational values, and within these two aspects, the underlying principles that affect the company's business excellence are presented. Leadership through mentorship of future leadership, orientation to customers, orientation to employees and a continuous improvement culture, along with the six organizational values that lead to organizational learning, pleasing the stakeholders and taking corporate social responsibility, ultimately produce business excellence.

This business excellence model is manifested through a successful business, satisfied employees and responsible membership in the community.

\section{Conclusion}

Organizational values are the subject of much research in contemporary management practice as well as in the business world. Organizational values play an important role in the business activities of modern organizations because they influence a business' strategy and its way of making decisions, which ultimately greatly influences its organizational effectiveness. Contemporary research places an increasing emphasis on balanced organizational values that are aimed at satisfying the needs of all stakeholders of organizations. Organizational values play a key role in achieving full excellence in all areas of business. 
This paper contribute by recognizing the connection between the concept of organizational values and business excellence, which is based on the квемS. The квемS combines two main aspectsleadership and organizational values-as two key elements that have an impact on achieving business excellence in the organization. Therefore, in this paper, the case of the American company Yum! Brands is presented as an example of a company whose business is based on organizational values and business excellence.

By analyzing the espoused organizational values of Yum! Brands, as well as by taking into consideration some external sources of information, we created Yum! Brands business excellence model, which is based on strong leadership and six core organizational values. Leadership through mentorship of future leadership, orientation to customers, orientation to employees and a continuous improvement culture are the organizational values that are the foundation for organizational learning, pleasing the stakeholders and taking corporate social responsibility-all of which lead to Yum! Brands' business excellence. This business excellence is manifested through a successful business, satisfied employees and a responsible member of the community.

Yum! Brands is a good example of how organizational values can be used to achieve excellence in all areas of business. The business model of Yum! Brands, which is based on organizational values and business excellence, can also serve as an example for other organizations that want to improve their business and operate in accordance with the concept of business excellence to achieve top business results and the satisfaction of all stakeholders.

\section{References}

Cardona, P., and C. Rey. 2008. Management by Missions. Basingstoke: Palgrave Macmillan.

Emberland, A. 2014. 'Yum! Brands' World Hunger Relief Has a RecordBreaking Year.' World Food Programme, 13 January. https://www .wfp.org/stories/yum-world-hunger-relief-has-record-breaking -year-fighting-world-hunger

Enz, C. A. 1988. 'The Role of Value Congruity in Intraorganizational Power.' Administrative Science Quarterly 33 (2): 284-304.

Fray, C. 2016. 'A Nearly Perfect Handling of a Crisis: KFC, a Little Girl, and a Little White Lie.' http://convergedmediamanagement.com/wp -content/uploads/KFCCrisis_ChelseaFray.pdf

Freeman, R. E. 1984. Strategic Management: A Stakeholder Approach. Boston, MA: Pitman.

Groves, K. S. 2007. 'Integrating Leadership Development and Succes-

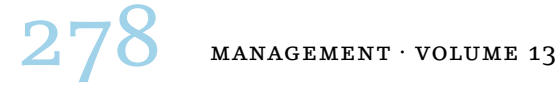


sion Planning Best Practices.' Journal of Management Development 26 (3): 239-6o.

Hultman, K., and B. Gellermann. 2002. Balancing Individual and Organizational Values: Walking the Tightrope to Success. San Francisco: Jossey-Bass.

Kanji, G. K. 1998. 'Measurement of Business Excellence.' Total Quality Management 9 (7): 633-43.

- 2002. 'Business Excellence: Make It Happen.' Total Quality Management 13 (8): 1115-24.

Kanji, G. K., and P. Moura e Sá. 2002. 'Kanji's Business Scorecard.' Total Quality Management 13(1): 13-27.

Kraak, V. I., P. B. Harrigan, M. Lowrence, P. J. Harrison, M. A. Jackson, and B. Swinburn. 2012. 'Balancing the Benefits and Risks of PublicPrivate Partnership to Address the Global Double Burden of Malnutrition.' Public Health Nutrition 15(3): 503-17.

Lencioni, P. M. 2002. 'Make Your Values Mean Something.' Harvard Business Review 8o (7): 113-7.

Malbašić, I. 2011. 'Tipologija organizacijskih vrijednosti.' Ekonomski pregled $62(7-8): 421-42$.

Malbašić, I., C. Rey, and V. Potočan. 2015. 'Balanced Organizational Values: From Theory to Practice.' Journal of Business Ethics 130 (2): 43746.

Rokeach, M. 1973. The Nature of Human Values. New York: Free Press.

Schwartz, S. H. 1992. 'Universals in the Content and Structure of Values: Theoretical Advances and Empirical Tests in 20 Countries.' Advances in Experimental Social Psychology 25:1-65.

Sikavica, P., F. Bahtijarević-Šiber, and N. Pološki Vokić. 2008. Temelji menadžmenta. Zagreb: Školska knjiga.

Sinha, S. B., and S. Kumar. 2012. 'Innovative HR Practices: Key Methods for Effective Talent Management.' Paper presented at the national seminar Inclusive Growth and Innovative Practices in Management, Ghaziabad, 15 April.

Zdrilić, I., and Ž. Dulčić. 2016. 'Business Excellence as a Success Factor for the Performance of Large Croatian Enterprises.' Management: Journal of Contemporary Management Issues 21 (1): 145-62. 